\title{
Mouse Chromosome 10
}

\author{
Benjamin A. Taylor, ${ }^{1, *}$ Wayne N. Frankel, ${ }^{1}$ Margit Burmeister, ${ }^{2}$ Elizabeth Bryda ${ }^{3}$ \\ ${ }^{1}$ The Jackson Laboratory, Bar Harbor, Maine 04609, USA \\ ${ }^{2}$ University of Michigan, Ann Arbor, Michigan 48109, USA \\ ${ }^{3}$ Wadsworth Center for Laboratories and Research, Albany, New York 12201, USA
}

Received: 2 June 1993

\section{Introduction}

The 1993 Mouse Chromosome (Chr) 10 report includes the addition of new genes and other DNA variants, their positions in the linkage and/or cytogenetic maps, deletions, recombinant inbred (RI) strain distribution patterns (SDPs), data pertaining to imprinting, and information about human-mouse linkage homology. New this year is a table showing the apparent gene order and recombination frequencies as determined in multilocus crosses.

Table 1 lists known Chr 10 loci alphabetically by gene symbols. Additional columns are used to denote (a) loci added to the list since the last report, (b) loci designated as reference loci, (c) the approximate map position in centimorgans from the centromere (if known), (d) localization to specific chromosomal bands, (e) classification of the loci (DNA, biochemical, visible, etc.), (f) the method(s) used in mapping, (g) the gene symbol of the human homolog (if known), (h) the location of the human homolog, and (i) selected references pertaining to the mapping of the mouse gene. Formerly used locus symbols are also listed alphabetically within the table.

\section{Chr 10 maps}

Figure 1 shows the updated versions of the "consensus map", the "proviral/RI map" and the "SSLP (simple sequence repeat length polymorphism) map". Only a few significant changes have been made to the consensus map. These are indicated in the legend of Fig. 1. Since there are few common loci between the proviral/RI and consensus maps, it is not yet possible to accurately place most RI markers on the consensus map.

\footnotetext{
*Chair of Committee for Mouse Chromosome 10
}

Table 2 shows the apparent gene order and recombination frequencies as estimated in seven different multilocus crosses. In all seven, either $M y b$ or $M p m v$ 12 and either Ifg or $M d m-1$ have been scored. $M y b$ and $M p m v-12$ are known to be closely linked (Frankel et al. 1990) as are Mdm-I and Ifg (Taylor et al. 1992). The MIT intercross involving Mus castaneus has not been typed for these markers but has been typed for markers known to be quite close to these markers. Thus, D10Mit4 is known to be close to Mpmv-12 (and hence, $M y b)$, and DlOMit14 is known to be close to $M d m-1$ (Dietrich et al. 1992a; Taylor et al. 1992). These seven crosses include three interspecific crosses involving Mus spretus and four intersubspecific crosses, two involving Mus castaneus and one each involving Mus musculus and Mus molossinus, and the pooled results of two small backcrosses involving conventional strains $\mathrm{C} 57 \mathrm{BL} / 6 \mathrm{~J}$ and $\mathrm{A} / \mathrm{J}$. The $(M y b / M p m v-12)-$ ( $M d m-1 / I f g$ ) two-point distance may be slightly underestimated in three of the crosses owing to undetected double crossovers between widely spaced markers. Six of the cumulative distance estimates are quite consistent with a mean of 56.1 (range: $48-64 \mathrm{cM}$ ). The Pasteur Mus spretus backcross (Cross B) gave a substantially shorter map distance $(40.7 \mathrm{cM})$. This is one of the smaller of the seven crosses in gametes analyzed $(\mathrm{N}=29-69)$. Thus, there is good evidence that the genetic distance between $M y b$ and $M d m-1 / I f g$ is approximately $56 \mathrm{cM}$. There are few common markers outside this interval, so there is greater uncertainty about map distances in the centrometric and telomeric regions.

Several adjustments have been made in the RI/ proviral map to accommodate new information. The orientation of $\mathrm{Hsd}$, Gad-lps, DIONds2, and $X m v-31$ has been reversed on the basis of RI strain typing of Mdm-1 and other data (Taylor et al. 1992; B.A. Taylor, unpublished data), although the revised order is not firmly established. Likewise, the position of $p g$ relative to D10Mit14 has been reversed. This is based on 
Table 1. Locus list for mouse Chr 10

\begin{tabular}{|c|c|c|c|c|c|c|c|c|c|c|}
\hline New & Symbol & Name & $\mathbf{A}$ & $\mathbf{M}$ & $\mathrm{CL}$ & $\mathrm{T}$ & Method & H. symbol & H. location & References \\
\hline & $A c p-2$ & See Apk & & & & & & & & \\
\hline & Act-2 & actin related gene-2 & & 8 & & D & $\mathbf{L}$ & & & 52 \\
\hline & $A d n$ & adipsin & & & & D, B & $\mathbf{S}$ & & & 104 \\
\hline & Ahi-1 & Abelson helper integration site & & 14 & & D & S, L & & & 52,88 \\
\hline & $A m h$ & anti-Mullerian hormone & & 41.5 & & D, B & $\mathbf{L}$ & AMH & 19 p13.3 & 54 \\
\hline & Apk & acid phosphatase-kidney (ex Acp-2) & & 32 & & B & $\mathbf{L}$ & & & 121,122 \\
\hline & Ass-ps2 & arginosuccinate synthetase pseudogene-2 & & & & D & $\mathbf{S}$ & & & 79 \\
\hline & $a t$ & atrichosis & & $66-72$ & & $\mathbf{V}$ & $\mathbf{L}$ & & & 49 \\
\hline & av & Ames waltzer & & 42 & & $\mathbf{V}$ & $\mathbf{L}$ & & & 80,95 \\
\hline & Bcr & breakpoint cluster region homolog & & 34.5 & & D & $\mathbf{L}$ & BCR & $22 q 11$ & 52 \\
\hline & $B p b$ & See Sio0b & & & & & & & & \\
\hline & Brof & Braf transforming gene & & 20.5 & & D, B & $\mathbf{L}$ & & & 52 \\
\hline & Bsg & basigin & & 39 & & $\mathrm{D}, \mathrm{B}$ & $\mathrm{L}$ & & & 101 \\
\hline & Cat & dominant cataract & & 72 & & V & $\mathrm{L}$ & & & $46,63,76$ \\
\hline & Cd18 & See Itgb2 & & & & & & & & \\
\hline & $C d c 2 a$ & cell division cycle 2 homolog, Chr 10 & & 33.5 & & $\mathrm{D}, \mathrm{B}$ & S, L & $\mathrm{CDC} 2$ & $10 \mathrm{q} 21.1$ & 52 \\
\hline & Cis & See Cs & & & & & & & & \\
\hline & $\operatorname{Cn} \times 43$ & See Gja-1 & & & & & & & & \\
\hline & Col6a-1 & procollagen type VI, alpha 1 & & 35.5 & & $\mathrm{D}, \mathrm{B}$ & S, L, P & COL6A1 & $21 \mathrm{q} 22.3$ & $52,65,89,90$ \\
\hline & Col6a-2 & procollagen type VI, alpha 2 & & 35.5 & & D, B & $\mathrm{S}, \mathrm{L}, \mathrm{P}$ & COL6A2 & $21 \mathrm{q} 22.3$ & 52,65 \\
\hline * & Colloa-1 & procollagen type $X$, alpha 1 & & 20.5 & & D, B & L & COL10A1 & $6 \mathrm{q} 21-22$ & 3 \\
\hline & $C s$ & citrate synthase (ex Cis, Cts) & & & & B & $\mathbf{S}$ & $\mathrm{CS}$ & 12p11-qter & 27 \\
\hline & $C t s$ & See Cs & & & & & & & & \\
\hline & DONds 22 & See D10Nds3 & & & & & & & & \\
\hline * & DIOBirl & DNA segment, Chr 10, Birkenmeier-1 & & $(58)$ & & $\mathrm{D}$ & $\mathbf{R}$ & & & 9 \\
\hline * & D10Bir2 & DNA segment, Chr 10, Birkenmeier-2 & & (2) & & D & $\mathbf{R}$ & & & 9 \\
\hline * & DIOBir3 & DNA segment, Chr 10, Birkenmeier-3 & & (3) & & $\mathrm{D}$ & $\mathbf{R}$ & & & 9 \\
\hline * & D10Byul & $\begin{array}{l}\text { DNA segment, Chr 10, } \\
\text { Brigham Young University-1 }\end{array}$ & & $(1.5)$ & & $\mathrm{D}$ & $\mathbf{R}$ & & & 123 \\
\hline & D10Cosl & DNA segment, Chr 10, Costantini-1 & & 29 & & $\mathrm{D}, \mathrm{B}$ & $\mathbf{L}$ & & & 52 \\
\hline & DIOH12S53E & $\begin{array}{l}\text { DNA segment, Chr 10, human D1 2S53E, } \\
\text { ex D12S53Eh (Pmell7; ?= silver) }\end{array}$ & & 69 & & $\mathrm{D}$ & $\mathrm{S}, \mathrm{L}$ & D12S53E & 12 pter-q21 & 56 \\
\hline & D1OLedl & $\begin{array}{l}\text { DNA segment, Chr 10, Leder-1, } \\
\text { ex D10Led3 }\end{array}$ & & $56-58$ & & $\mathrm{D}$ & $\mathrm{L}$ & & & 7,48 \\
\hline & D10Led3 & See Dioled 1 & & & & & & & & \\
\hline$*$ & Dlocerl & DNA segment, Chr 10, Le Roy-1 & & 3 & & $\mathrm{D}$ & L & & & 60 \\
\hline * & DIOLer2 & DNA segment, Chr 10, Le Roy-2 & & 78 & & $\mathrm{D}$ & $\mathbf{L}$ & & & 60 \\
\hline * & $\mathrm{D} 10 \mathrm{Mc} 2$ & DNA segment, Chr 10, McClelland-2 & & (55) & & D & $\mathbf{R}$ & & & 116 \\
\hline & DlOMitl & DNA segment, Chr 10, MIT-1 & & (5) & & $\mathrm{D}$ & $\mathrm{L}$ & & & 30 \\
\hline & DIOMit2 & DNA segment, Chr 10, MIT-2 & & (10) & & $\mathrm{D}$ & $\mathbf{L}, \mathbf{R}$ & & & 30 \\
\hline & DlOMit3 & DNA segment, Chr 10, MIT-3 & & (15) & & D & $\mathbf{L}$ & & & 30 \\
\hline & DlOMit4 & DNA segment, Chr 10, MIT-4 & & (14) & & D & $\mathbf{L}$ & & & 30 \\
\hline & D10Mit5 & DNA segment, Chr 10, MIT-5 & & $(22)$ & & D & $\mathrm{L}$ & & & 30 \\
\hline & D10Mit7 & DNA segment, Chr 10, MIT-7 & & (43) & & $\mathbf{D}$ & $\mathbf{L}$ & & & 30 \\
\hline & DlOMit8 & DNA segment, Chr 10, MIT-8 & & (45) & & $\mathbf{D}$ & $\mathbf{L}$ & & & 30 \\
\hline & Dlomits & DNA segment, Chr 10, MIT-9 & & (51) & & D & $\mathbf{L}$ & & & 30 \\
\hline & DIOMitIO & DNA segment, Chr 10, MTT-10 & & (53) & & D & $\mathbf{L}, \mathbf{R}$ & & & 30 \\
\hline & DIOMit11 & DNA segment, Chr 10, MTT-11 & & (53) & & $\mathrm{D}$ & $\mathbf{L}, \mathbf{R}$ & & & 30 \\
\hline & DloMit12 & DNA segment, Chr 10, MIT-12 & & (54) & & $\mathrm{D}$ & $\mathrm{L}$ & & & 30 \\
\hline & D10Mit13 & DNA segment, Chr 10, MTT-13 & & (64) & & $\mathbf{D}$ & $\mathbf{L}$ & & & 30 \\
\hline & D10Mit14 & DNA segment, Chr 10, MT- 14 & & $(72)$ & & $\mathrm{D}$ & $\mathbf{L}, \mathbf{R}$ & & & 30 \\
\hline & DIOMitls & See D10Mit20 & & & & & & & & \\
\hline * & D10Mit16 & DNA segment, Chr 10, MTT-16 & & $(11)$ & & $\mathbf{D}$ & $\mathrm{L}$ & & & 31 \\
\hline * & D10Mit17 & DNA segment, Chr 10, MTT-17 & & (11) & & D & $\bar{L}$ & & & 31 \\
\hline * & D10Mit19 & DNA segment, Chr 10, MTT-19 & & (23) & & D & $\mathbf{L}$ & & & 31 \\
\hline * & DIOMi20 & DNA segment, Chr 10, MTT-20 & & (26) & & D & $\mathrm{L}$ & & & 31 \\
\hline & & (=D10Mit15, Sqr3) & & & & & & & & \\
\hline * & DlOMit21 & DNA segment, Chr 10, MTT-21 & & (43) & & $\mathrm{D}$ & $\mathrm{L}$ & & & 31 \\
\hline * & D10Mit22 & DNA segment, Chr 10, MIT-22 & & (43) & & $\mathrm{D}$ & $\mathrm{L}$ & & & 31 \\
\hline * & D10Mit23 & DNA segment, Chr 10, MIT-23 & & (43) & & $\mathrm{D}$ & $\mathrm{L}$ & & & 31 \\
\hline * & D1OMit24 & DNA segment, Chr 10, MTT-24 & & (72) & & D & L & & & 31 \\
\hline * & D10Mit25 & DNA segment, Chr 10, MTT- 25 & & $(77)$ & & D & $\mathbf{L}$ & & & 31 \\
\hline * & D10Mit28 & DNA segment, Chr 10, MTT-28 & & (3) & & D & I. & & & 31 \\
\hline$*$ & DloMit29 & DNA segment, Chr 10, MTT-29 & & (23) & & $\mathrm{D}$ & $\mathrm{L}$ & & & 31 \\
\hline * & D10Mit30 & DNA segment, Chr 10, MIT-30 & & (23) & & D & $\mathbf{L}$ & & & 31 \\
\hline * & D10Mit31 & DNA segment, Chr 10, MIT-31 & & (33) & & D & $\mathbf{L}$ & & & 31 \\
\hline * & D10Mit32 & DNA segment, Chr 10, MIT-32 & & (36) & & $\mathrm{D}$ & $\bar{L}$ & & & 31 \\
\hline * & DIOMit33 & DNA segment, Chr 10, MTT-33 & & (64) & & D & $\mathbf{L}$ & & & 31 \\
\hline * & DIOMit34 & See D10Mit33 & & & & & & & & \\
\hline * & D10Mit35 & DNA segment, Chr 10, MIT-35 & & $(77)$ & & $\mathbf{D}$ & $\mathbf{L}$ & & & 31 \\
\hline * & D10Mit36 & DNA segment, Chr 10, MIT-36 & & & & $\mathbf{D}$ & $\mathbf{L}$ & & & 31 \\
\hline * & D10Mit38 & DNA segment, Chr 10, MIT-38 & & $(22)$ & & D & $\overline{\mathbf{L}}$ & & & 31 \\
\hline * & DIOMit40 & DNA segment, Chr $10, \mathrm{MTT}-40$ & & $(22)$ & & D & $\mathbf{L}$ & & & 31 \\
\hline * & D10Mit4l & DNA segment, Chr 10, MIT -41 & & (53) & & $\mathrm{D}$ & $\mathbf{L}$ & & & 31 \\
\hline * & D10Mit42 & DNA segment, Chr 10, MIT 42 & & (44) & & D & $\mathrm{L}$ & & & 31 \\
\hline * & DIOMit43 & DNA segment, Chr 10, MTT 43 & & (53) & & D & $\mathrm{L}$ & & & 31 \\
\hline
\end{tabular}


Table 1. Continued.

\begin{tabular}{|c|c|c|c|c|c|c|c|c|c|c|}
\hline New & Symbol & Name & & $\mathbf{M}$ & $C L$ & $\mathrm{~T}$ & Method & H. symbol & H. location & References \\
\hline$*$ & DIOMi144 & DNA segment, Chr 10, MIT-44 & & (17) & & $\mathbf{D}$ & $\mathbf{L}$ & & & 31 \\
\hline * & DIOMit45 & DNA segment, Chr 10, MIT-45 & & (17) & & D & $\mathbf{L}$ & & & 31 \\
\hline * & DIOMit46 & DNA segment, Chr 10, MIT -46 & & (67) & & $\mathbf{D}$ & $\mathbf{L}$ & & & 31 \\
\hline * & D10Mit47 & DNA segment, Chr $10, \mathrm{MTT}-47$ & & (67) & & D & $\mathbf{L}$ & & & 31 \\
\hline \multirow[t]{6}{*}{ * } & D10Mit48 & DNA segment, Chr 10, MIT- 48 & & (24) & & $\mathbf{D}$ & $\mathbf{L}$ & & & 31 \\
\hline & DIONdsl & $\begin{array}{l}\text { DNA segment, Chr } 10 \text {, } \\
\text { Nuffield Department of Surgery-1 }\end{array}$ & & (3) & & D & $\mathbf{L}, \mathbf{R}$ & & & 26,30 \\
\hline & DIONds2 & $\begin{array}{l}\text { DNA segment, Chr 10, } \\
\text { Nuffield Department of Surgery-2 }\end{array}$ & & (59) & & D & $\mathbf{L}, \mathbf{R}$ & & & 26,30 \\
\hline & D10Nds3 & $\begin{array}{l}\text { DNA segment, Chr } 10 \text {, } \\
\text { Nuffield Department of Surgery-3 } \\
\text { (ex DONds } 22 \text { ) }\end{array}$ & & (22) & & $\mathrm{D}$ & L & & & 26,30 \\
\hline & DlopasI & DNA segment, Chr 10, Pasteur Institute-1 & & 37.5 & & $\mathbf{D}$ & $\mathbf{L}$ & & & 15 \\
\hline & D10Pas2 & DNA segment, Chr 10, Pasteur Institute-2 & & 32.5 & & $\mathbf{D}$ & $\mathbf{L}$ & & & 15 \\
\hline \multirow[t]{14}{*}{ * } & $\begin{array}{l}\text { DIOPas3 } \\
\text { DI2S53Eh }\end{array}$ & $\begin{array}{l}\text { DNA segment, Chr 10, Pasteur Institute-3 } \\
\text { See D10H12S53E }\end{array}$ & & 32.5 & & D & $\mathbf{L}$ & & & 97 \\
\hline & $d l$ & downless & & 29.5 & & V, D & $\mathrm{L}, \mathrm{S}$ & & & $\begin{array}{l}28,4187,98 \\
107,122\end{array}$ \\
\hline & Dmall & dystrophin-like & & 0.5 & & D, B & $\mathbf{L}$ & DMDL & $6 q 24$ & 15 \\
\hline & dy & dystrophia muscularis & & 9 & & $\mathbf{V}$ & $\mathbf{L}$ & & & $18,91,107,120$ \\
\hline & $e b$ & eye blebs & & $66-72$ & & V & $\mathbf{L}$ & & & 49 \\
\hline & $E_{g r-2}$ & early growth response-2 & & & B5 & D, B & I & EGR2 & $10 \mathrm{q} 21.1$ & 24,51 \\
\hline & Emv-25 & endogenous ecotropic MuLV-25 & & 9 & & $\mathbf{D}$ & $\mathbf{L}$ & & & 111 \\
\hline & Estr & estrogen receptor & & 9.5 & & D, B & $\mathbf{L}$ & ESR & $6 \mathrm{q} 24-27$ & 52 \\
\hline & Fisp 12 & fibroblast-inducible secreted protein & & & A3-B1 & D, B & I & & & 93 \\
\hline & Fyn & Fyn proto-oncogene & & 21.5 & & D, B & $\mathbf{L}$ & FYN & $6 \mathrm{q} 21$ & 52 \\
\hline & Gad-Ips & glutamic acid decarboxylase-1 pseudogene & & (57) & & D & $\mathbf{R}$ & & & 14 \\
\hline & Gja-I & $\begin{array}{l}\text { gap junction membrane channel } \\
\text { protein alpha-1 (ex Cxn43) }\end{array}$ & & 26.5 & & D, B & $\mathbf{S}$ & GJA1 & $6 \mathrm{q} 14-\mathrm{q} 24.1$ & 45,47 \\
\hline & $8 l$ & grey-lethal & & $20-47$ & & $\mathbf{V}$ & $\mathbf{L}$ & & & 58 \\
\hline & $G l i$ & human glioma associated oncogene & 1 & 67 & & D, B & $\mathbf{S}, \mathbf{L}, \mathbf{R}$ & GLI & $12 q 13$ & 52,55 \\
\hline * & Gnaz & $\begin{array}{l}\text { guanine nucleotide binding protein, } \\
\text { alpha } \mathrm{z} \text { subunit }\end{array}$ & & 34.5 & & D, B & L & GNAZ & $22 \mathrm{q} 11$ & 117 \\
\hline * & Gnall & $\begin{array}{l}\text { guanine nucleotide binding protein, } \\
\text { alpha subunit-11 }\end{array}$ & & 37.5 & & D, B & $\mathbf{L}$ & GNA11 & $19 p 13$ & 117 \\
\hline \multirow[t]{3}{*}{ * } & Gnals & $\begin{array}{l}\text { guanine nucleotide binding protein, } \\
\text { alpha subunit-15 }\end{array}$ & & 37.5 & & D, B & L & GNA15 & $19 \mathrm{p} 13$ & 117 \\
\hline & $8 r$ & grizzled & & 44 & & V & $\mathbf{L}$ & & & $6,43,64,92$ \\
\hline & Hal & histidine ammonia lyase & & & C3-D1 & D, B & I & HAL & $12 \mathrm{q} 22-24.1$ & 113 \\
\hline \multirow[t]{2}{*}{ * } & Hclo & heterochromatin, $\mathrm{Chr} 10$ & & 0 & A1 & D & $\mathrm{I}, \mathrm{L}$ & & & 23 \\
\hline & hes & hesitant & & 42 or 72 & & $\mathbf{V}$ & & & & 106 \\
\hline \multirow[t]{4}{*}{$*$} & hg & high growth & & 47 & & $\mathrm{~V}, \mathrm{~B}$ & L & & & 71 \\
\hline & his & histidinemia (mutation at Hal locus?) & & $48-66$ & & $\mathbf{V}, \mathbf{B}$ & $\mathbf{L}$ & & & 53 \\
\hline & $H k-1$ & hexokinase-1 & & 30.5 & & $\mathbf{B}$ & S, L & HK1 & $10 \mathrm{q} 22$ & 57,86 \\
\hline & $H s d$ & $\begin{array}{l}\text { histidase synthetic rate } \\
\text { (variant at Hal locus?) }\end{array}$ & & 56 & & $\mathbf{B}$ & $\mathbf{R}, \mathbf{L}$ & & & 4 \\
\hline \multirow[t]{9}{*}{ * } & lapls3-21 & intra-cisternal A particle LTR sequence 3-21 & & & & D & $\mathbf{R}$ & & & 62 \\
\hline & If & interferon gamma & & 64 & & D, B & $\mathbf{S}, \mathrm{L}, \mathbf{R}$ & IFNG & $12 q 24.3$ & $\begin{array}{l}52,55,77,81 \\
100,108,112\end{array}$ \\
\hline & Ifgr & interferon gamma receptor & & 13 & & D. B & S, L & IFNGR 1 & $6 q 23-24$ & 55,68 \\
\hline & $I g f-1$ & insulin-like growth factor- 1 & & 46 & & $\mathrm{D}, \mathbf{B}$ & S, L & IGF1 & $12 \mathrm{q} 23$ & 52,109 \\
\hline & $\lg g 2$ & integrin beta-2, ex Cd18, Lfa-1, Mac-1 & & 36.5 & & $\mathrm{D}, \mathrm{B}$ & $\mathbf{S}, \mathbf{P}$ & ITGB2 & $21 \mathrm{q} 22.3$ & $65,66,90,115$ \\
\hline & $j c$ & Jackson circler. & & 29.5 & & $\mathbf{V}$ & $\mathrm{L}$ & & & 42,103 \\
\hline & $\ddot{j i}$ & jittery & & $34-47$ & & $\mathbf{V}$ & $\mathrm{L}$ & & & 29 \\
\hline & kd & kidney disease & & 28 & & V & $\mathrm{L}$ & & & 63 \\
\hline & Lfa-I & See Itgb2 & & & & & & & & \\
\hline$*$ & $L m m b 2$ & lamin B2 & & & $10 C$ & D, B & I & LMNB2 & 19 p13.3 & 8,125 \\
\hline \multirow[t]{2}{*}{$*$} & $L y-41$ & $\begin{array}{l}\text { (Pca-1) lymphocyte alloantigen- } 41 \text {; membrane } \\
\text { glycoprotein (alkaline phosphodiesterase I); } \\
\text { plasma cell antigen-1 }\end{array}$ & & (18) & & $\mathrm{D}, \mathrm{B}$ & $\mathbf{R}$ & M6Si & $6 \mathrm{q} 22-23$ & 16 \\
\hline & Mac-1 & See ligb2 & & & & & & & & \\
\hline \multirow[t]{3}{*}{$*$} & Macs & $\begin{array}{l}\text { myristolated alanine-rich } \\
\text { protein kinase } C \text { substrate }\end{array}$ & & 20.5 & & D, B & L & MACS & $6 \mathrm{q} 21$ & 10 \\
\hline & $M d m-1$ & transformed mouse 3T3 cell double minute-1 & & 64 & $\mathbf{C}$ & $\mathrm{D}, \mathrm{B}$ & $\mathbf{S}, \mathbf{I}, \mathbf{L}, \mathbf{R}$ & MDM1 & 12 & $15,19,112$ \\
\hline & $M d m-2$ & transformed mouse $3 \mathrm{~T} 3$ cell double minute- 2 & & & C & $\mathrm{D}, \mathrm{B}$ & S, I & MDM2 & $12 q 13-14$ & 19 \\
\hline \multirow[t]{8}{*}{ * } & $\begin{array}{l}M d m-3 \\
M g f\end{array}$ & $\begin{array}{l}\text { transformed mouse } 3 \mathrm{~T} 3 \text { cell double minute-3 } \\
\text { mast cell growth factor (see } \mathrm{Sl} \text { ) }\end{array}$ & & & & $\mathrm{D}, \mathrm{B}$ & $\mathbf{S}, \mathbf{P}$ & & & 19,32 \\
\hline & $m h$ & mocha & & 44 & & V & $\mathbf{L}$ & & & 41,59 \\
\hline & Minta & murine leukemia virus integration site $\mathbf{A}$ & & 39.5 & & $\mathrm{D}$ & $\mathbf{L}$ & & & 108 \\
\hline & Mip & $\begin{array}{l}\text { major intrinsic protein of } \\
\text { eye-lens-fiber cell membranes }\end{array}$ & & & D1 & D, B & I & MIP & 12 cen-q 14.3 & 44 \\
\hline & $M p m v-5$ & modified polytropic murine leukemia virus-5 & & $(0.5)$ & & $\mathrm{D}$ & $\mathbf{R}, \mathbf{L}$ & & & 40 \\
\hline & $M p m v-12$ & modified polytropic murine leukemia virus-12 & & (23) & & D & $\mathbf{R}, \mathbf{L}$ & & & 40 \\
\hline & $M p m y-40$ & modified polytropic murine leukemia virus -40 & & (25) & & D & $\mathbf{L}$ & & & 36 \\
\hline & $M s 6-3$ & minisatellite sequence 6-3 & & (67) & & $\mathbf{D}$ & $\mathbf{R}$ & & & 50 \\
\hline
\end{tabular}


Table 1. Continued.

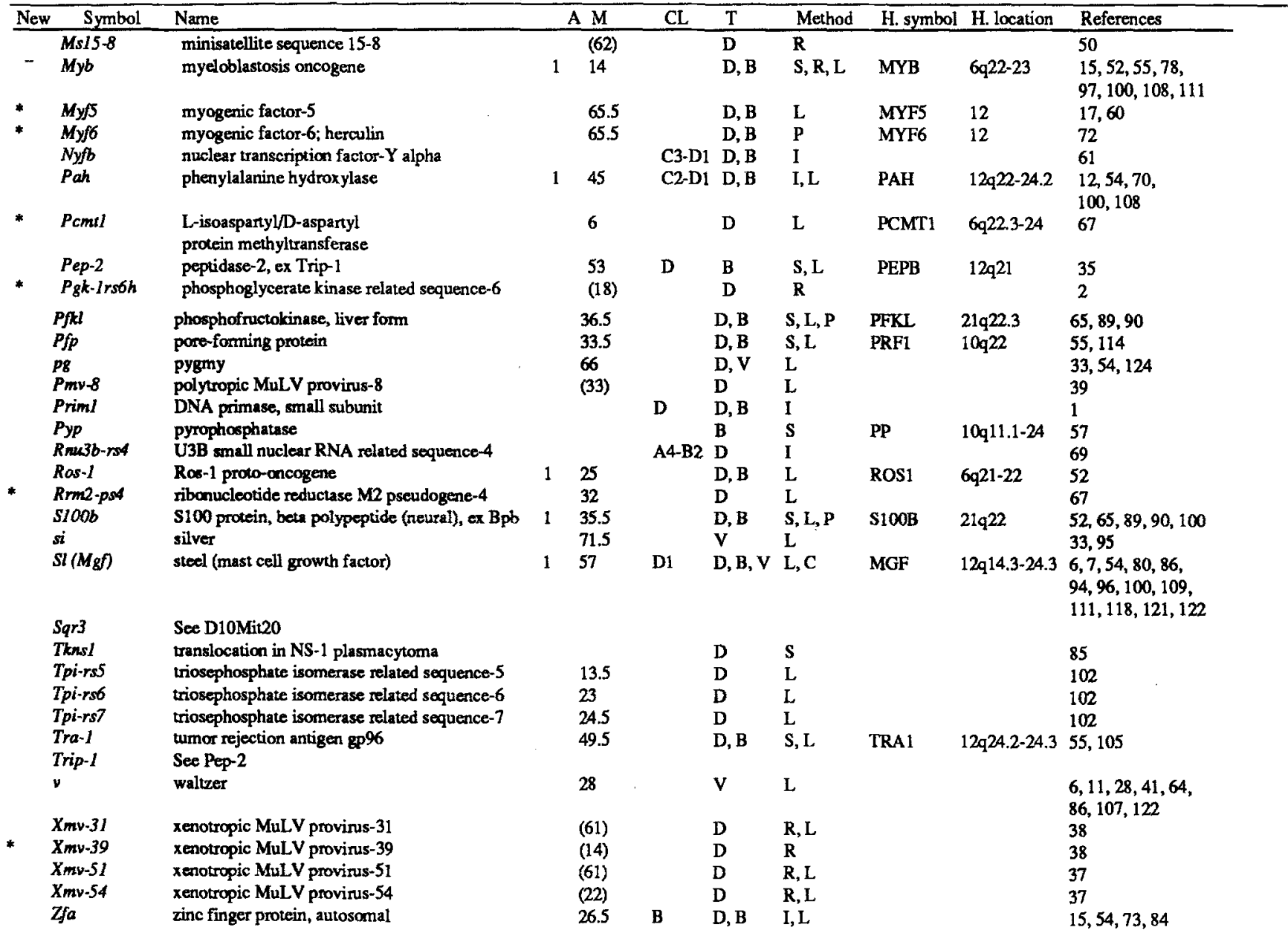

An asterisk in the "New" column denotes a new locus added to last year's list. In the "A" column, " 1 " denotes a primary reference locus. The "M" column-map position-gives the estimated distance from the centromere The numbers shown in parentheses denote map positions inferred primarily from RI strain data or the MIT intercross. The parentheses are intended to indicate that these loci are not necessarily well-integrated in the consensus map. The "CL" column-cytogenetic localization-gives localization to specific chromosomal bands by in situ hybridization or analysis of chromosoma rearrangements. In the "T" column, D = DNA (any locus defined by a DNA

the apparent close linkage between D10Mit14 and $M d m-1$ ( $0 / 16$ recombinants in the BXD RI strains) and the very close linkage between $M d m-1$ and Ifg. Since $p g$ is distal to $I f g$, it is likely to be distal to $M d m-1$ as well.

Figure 2 shows the updated Chr 10 cytogenetic map. Several new deletions involving the steel locus have been added (see below).

\section{Microsatellite variants}

The major addition to the $\mathrm{Chr} 10$ map consists of 28 additional SSLPs (Dietrich et al. 1992a). These 28 markers were mapped by use of 46 (C57BL/6J-ob $\times$ $\mathrm{CAST} / \mathrm{Ei}) \mathrm{F}_{2}$ mice. Recombination frequencies are not provided for individual linkages, so the map shown here (Fig. 1) is based primarily on the map shown by the authors. The new markers do not extend the SSLP map beyond the previous range of $\sim 75 \mathrm{cM}$. If these sequence or clone); $\mathrm{P}=$ PCR primers; $\mathrm{B}=$ biochemical/protein/ immunological; and $\mathrm{V}=$ visible/other phenotype. In the "Method" column, $\mathbf{I}=$ in situ hybridization; $\mathbf{S}=$ somatic cell genetics; $\mathrm{R}=\mathrm{RI}$ strains; $\mathrm{L}=$ linkage analysis by backcross or intercross; $\mathrm{C}=$ cytogenetic analysis (translocations, visible deletions, etc.); $\mathrm{D}=$ deletion analysis (molecular); $\mathbf{H}=$ radiation hybrid analysis; and $\mathrm{P}=$ physical mapping (PFGE, YACS, etc.). Information on human genes was taken from the human genomic database, GDB. Evidence for Chr 10 linkage of $P g k-1 r s 6$ is identity of SDP with $L y-41$ in $12 \mathrm{BXH}$ RI strains.

markers are randomly distributed over the linkage map, then it is unlikely that total map distance is much greater than 75 centimorgans (cM), at least as determined in this particular cross $(n=46)$. A subset of the DIOMit markers have been mapped with respect to other markers in the 'Copeland-Jenkins' interspecific backcross. Although preliminary results were presented at the Buffalo meeting (Weaver et al. 1992), the merger of these two maps awaits publication of the data.

\section{A centromeric marker}

Also reported at the Buffalo meeting was an estimated distance between the subcentromeric heterochromatin found in most laboratory strains and the $M y b$ locus (Ceci et al. 1992). The centromeric heterochromatin marker, Hcl0, was scored in (C57BL/6Ros $\times$ Mus 

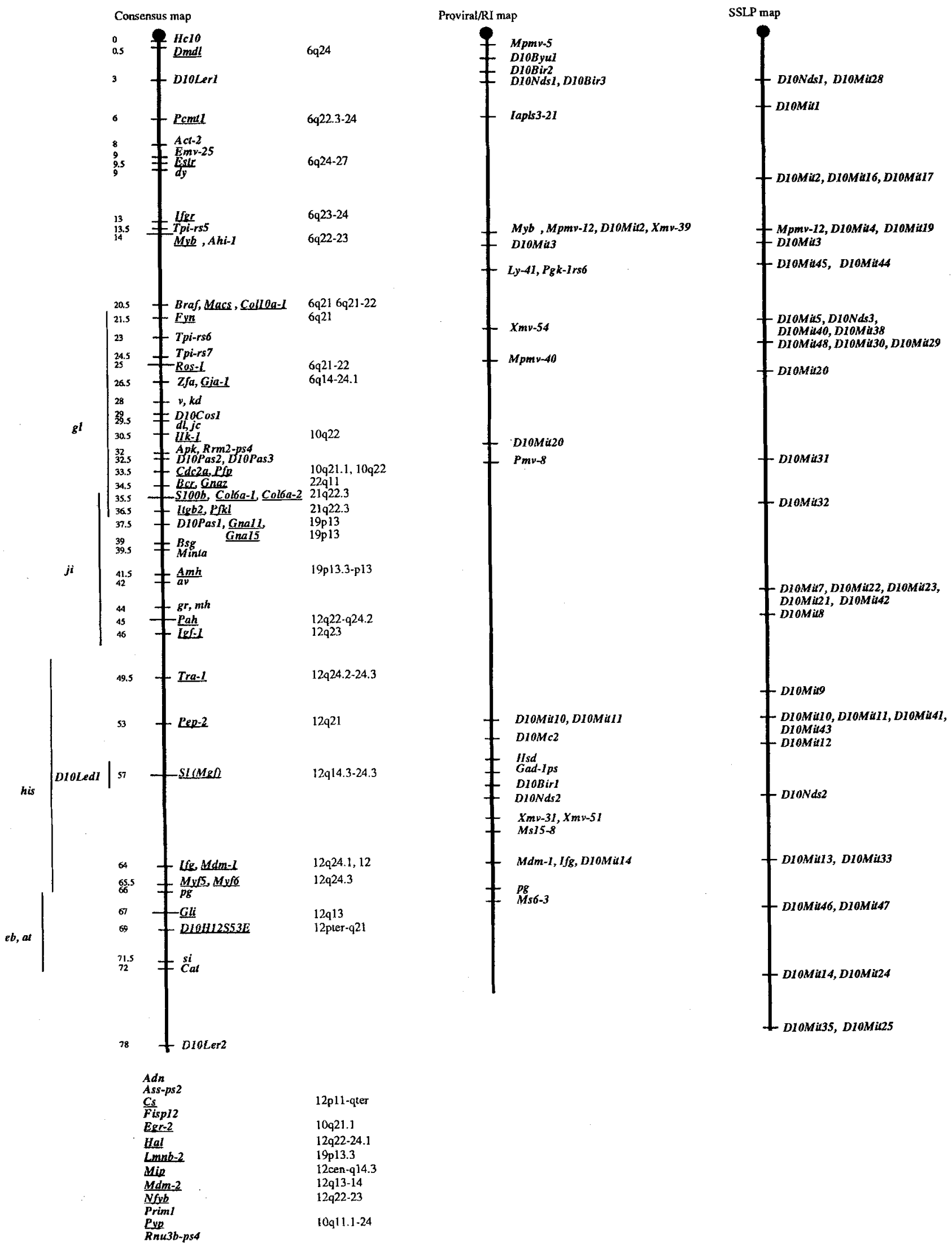
Table 2. Gene order and recombination frequencies determined by multipoint crosses.

\begin{tabular}{|c|c|c|c|}
\hline Crosses: gene order and recombination frequencies \pm standard error & $\begin{array}{l}\text { Total map } \\
\text { length } \\
\text { (cM) }\end{array}$ & $\begin{array}{l}\text { No. of } \\
\text { progeny }\end{array}$ & References \\
\hline 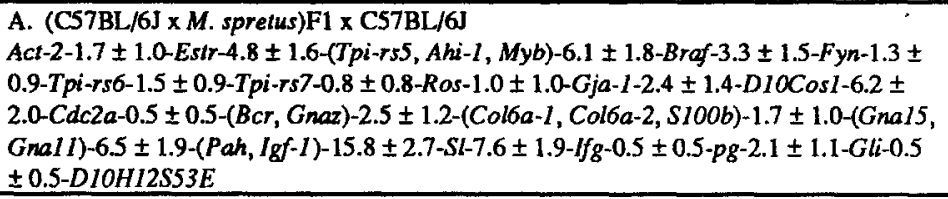 & 68.4 & $104-199$ & $\begin{array}{l}25,52,56, \\
102,117\end{array}$ \\
\hline 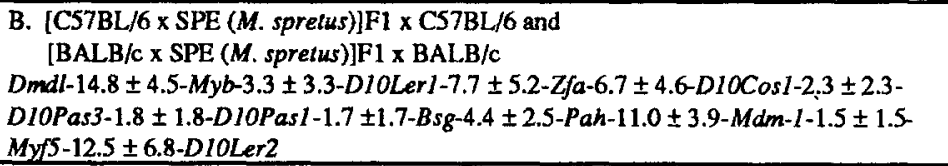 & 67.7 & $26-69$ & $\begin{array}{l}15,60,73, \\
97, \text { and J.-L. } \\
\text { Guenet, p.c. }\end{array}$ \\
\hline $\begin{array}{l}\text { C. C3H/HeJ-gld } \times \text { M. spretus)F1 } \times \text { C3H/HeJ-gld } \\
\text { Myb-7.0 } \pm 2.4-(\text { CollOa-1, Braf, Macs)-0.9 } \pm 0.9-F y n-25.4 \pm 4.1-\text { Minta-6.1 } \pm 2.2-P a h- \\
18.3 \pm 3.6-\text { Ifg }\end{array}$ & 57.7 & 114 & $\begin{array}{l}3,10,108, \\
\text { M. Seldin, } \\
\text { p.c. }\end{array}$ \\
\hline 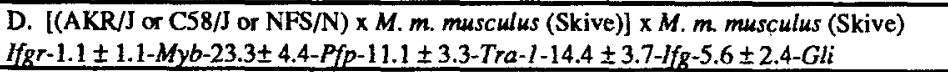 & 55.5 & 90 & 55 \\
\hline $\begin{array}{l}\text { E. (BXD-32 or SWR/J) } \times \text { (CAST/Ei x MEV)F1 } \\
\text { Emv-25-6.3 } \pm 2.5-M y b-26.7 \pm 4.7-1 g f-1-11.3 \pm 3.8-S l-18.5 \pm 4.3-(J f g, M d m-1)\end{array}$ & $\overline{62.8}$ & $71-95$ & $\begin{array}{l}109,111, \\
112\end{array}$ \\
\hline $\begin{array}{l}\text { F. }(129 / \mathrm{Sv}-\mathrm{S} l /+\times \text { MOL-MIT)F1 } \times 129 / \mathrm{SvJ}-+1+ \\
M y b-34.9 \pm 4.6-S 100 b-8.5 \pm 2.7-P a h-8.5 \pm 2.7-S /-12.3 \pm 3.2-1 f g\end{array}$ & 64.2 & 106 & 100 \\
\hline $\begin{array}{l}\text { G. (CS7BL/6J × M. spretus)F1 x C57BL/6J } \\
P c m 11-8.2 \pm 3.5-M y b-23.0 \pm 5.4-R r m 2-4 p s-13.1 \pm 4.3-P a h\end{array}$ & 44.3 & 61 & 67 \\
\hline $\begin{array}{l}\text { H. } \mathrm{A} / \mathrm{J} \times(\mathrm{A} / \mathrm{J} \times \mathrm{C} 57 \mathrm{BL} / 6 \mathrm{~J}) \mathrm{F} 1 \text { and }(\mathrm{A} / \mathrm{J} \times \mathrm{C} 57 \mathrm{BL} / 6 \mathrm{~J}) \mathrm{F} 1 \times \mathrm{C} 57 \mathrm{BL} / 6 \mathrm{~J} \\
\text { D10Nds1-10.0 } \pm 4.7-D 10 \mathrm{Mil} 2-27.5 \pm 7.1-D 10 \mathrm{Mit} 10-22.5 \pm 6.6-D 10 \mathrm{Mit} 14\end{array}$ & 60.0 & 40 & 75 \\
\hline
\end{tabular}

spretus) $\times$ Mus spretus interspecific backcross progeny by in situ hybridization with a major satellite DNA probe. The estimated distance, $12.4 \mathrm{cM}$, provides a minimal distance between $M y b$ and the centromeric telomere. This result is at variance with the prior placement of $D m d l$ marker at a position $23 \mathrm{cM}$ proximal to $M y b$. Recently, the $D m d l-M y b$ distance has been reduced to $13.5 \mathrm{cM}$ (J.-L. Guénet, personal communication). The latter value is more consistent with the $H c 10-M y b$ distance.

\section{New gene loci}

Nine newly identified genes (each defined by a DNA probe) have been added to $\mathrm{Chr} 10$. Three guanine nucleotide-binding protein subunit genes have been mapped (Wilkie et al. 1992). Two of these (guanine nucleotide-binding protein alpha subunit-11 and -15) failed to recombine in a $M$. spretus backcross and are reported to be closely linked physically as well. A third gene, (guanine nucleotide-binding protein, alpha $\mathrm{z}$ subunit) maps just $1 \mathrm{cM}$ proximal to the other two. The genes encoding myristolated, alanine-rich protein kinase $\mathrm{C}$ substrate $(\mathrm{Macs})$ and procollagen type $\mathrm{X}$ alpha 1 subunit (CollOa-1) fail to recombine with one another or the previously mapped Braf gene (Apte et al. 1992; Blackshear et al. 1992). The myogenic differentiation factor-5 gene (Myf5) was reported to map distal to $M d m-1$ (Le Roy et al. 1992; J.-L. Guénet, pers. comm.). The lamin B2 gene (Lmnb-2) was assigned to the $\mathrm{Chr} 10 \mathrm{C}$ band by in situ hybridization (Zewe et al. 1991). The gene encoding L-isoaspartyl/ D-aspartyl protein methyltransferase $(P c m t I)$ was mapped $8.2 \pm 3.5 \mathrm{cM}$ proximal to $M y b$ (MacLaren et
Fig. 1. Comprehensive maps of $\mathrm{Chr} \mathrm{10.} \mathrm{The} \mathrm{consensus} \mathrm{map} \mathrm{on} \mathrm{the}$ left represents a map compiled with multilocus and two-point cross data. All genes that have been mapped in human are underlined, and the location in the human map is given to the right of the chromosome. Reference loci are indicated by a wider bar. Loci that have been mapped in two-point crosses only are shown as bars to the left of the chromosome. Loci that have been assigned to Chr 10 on the basis of somatic cell hybrids are listed at the bottom of the chromosome. The following changes have been made to the consensus map: a) the distance between $D m d l$ and $M y b$ was reduced to $13.5 \mathrm{cM}$, thus moving all loci except $D m d l$ up $9 \mathrm{cM}$, b) a subcentromeric heterochromatin marker $(H c I 0)$ was placed at position $0.0, \mathrm{c})$ the following new loci have been added (proximal to distal): DIOLerl, Pcmt1, Macs, Coll0a-1, Rrm2-ps4, Gnaz, Gnal1, Gna15, Myf5, and Dl0Ler2; d) Pfkl was moved to a more proximal position based on revised mapping data and homology considerations; e) the locus symbol $C d 18$ has been replaced by $1 \mathrm{tg} b 2$; f) $M d m-1$ was moved alongside $I f g$.

The RI/proviral map represents data from RI strains as well as from a $(\mathrm{DBA} / 1 \mathrm{~J} \times 129 / \mathrm{J}) \mathrm{F}_{1} \times 129 / \mathrm{J}(\mathrm{DX} 1 \mathrm{X} 1)$ cross (Frankel et al. 1991), reciprocal backcrosses between NZB/BINJ and SM/J (Frankel et al. 1992) and the typing of RI strains for microsatellite sequences. The following changes to the proviral/RI map should be noted: a) the following loci have been added based on RI strain mapping data: D10Byu1, D10Bir3, D10Bir2, Iapls3-21, Xmv-39, Ly41, Pgk-rs6, DIOMc2, DIOBirl, Ifg, and $M d m-1$; b) the order of $M s 15-8, X m v-31, X m v-51, D 10 N d s 2, G a d-1 p s$, and Hsd has been reversed; c) DIOMit14 and $M s 6-3$ have been moved to a more proximal position on the basis of the apparent close linkage of DIOMit14 to $M d m-1$; d) $M d m-1$ and DIOMit14 are shown proximal to $p g$ based on the close linkage of $M d m-1$ to $I f g$. e) the locus symbol of DIOMit 5 has been replaced by D1OMit20; f) $M p m v-5$ is moved closer to $M y b$ and $M p m v-12$ on the basis of new backcross data; g) D10Nds1 is placed close to, but distal to, $M p m v-5$ based on AXB and BXA RI data.

The SSLP map on the right is a representation of the map presented by Dietrich and colleagues (1992a, b). 
Chromosome 10

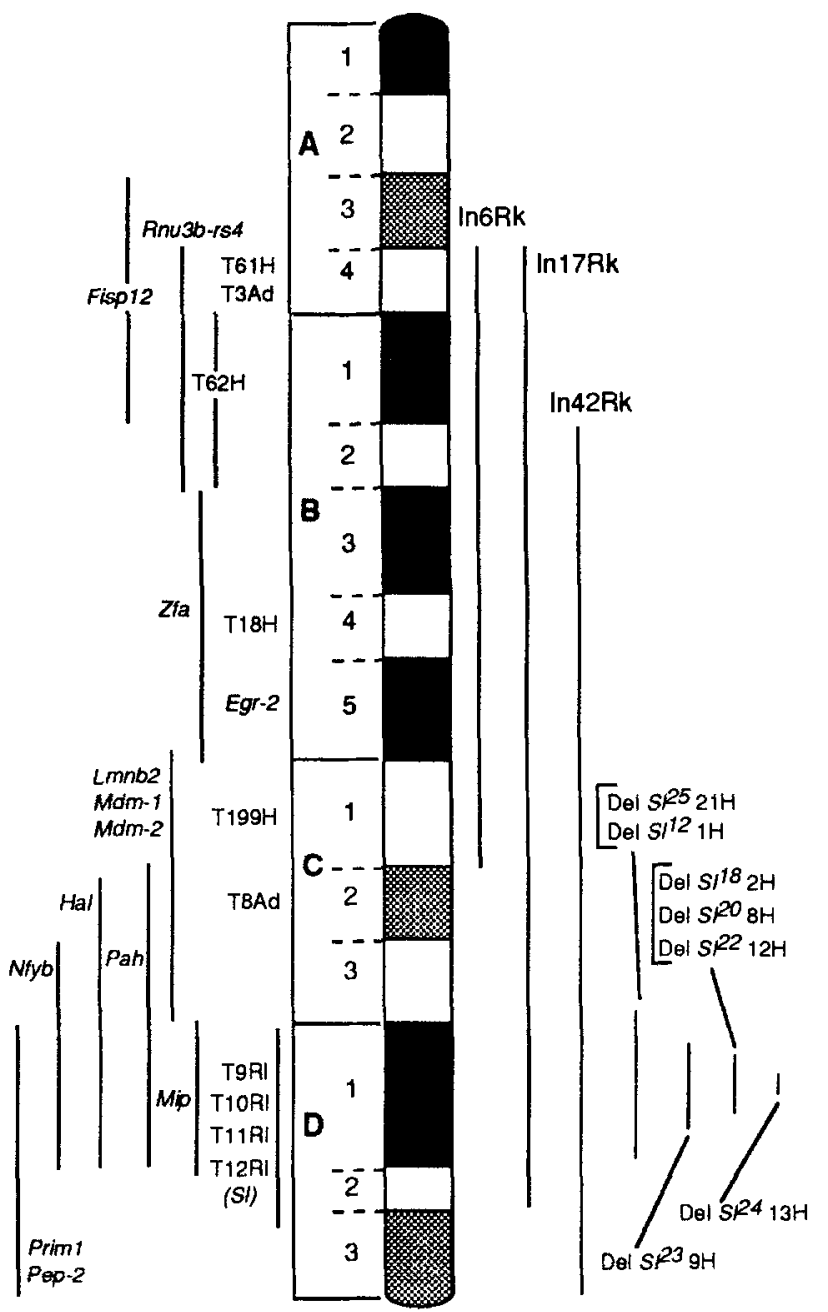

Fig. 2. Cytogenetic map of Chr 10 showing the banding pattern of Nesbitt and Francke (1973) with the positions of inversions, translocations, deletions, and loci mapped by in situ hybridization. New deletions at the $S l$ locus have been added. $L m n b-2$ has been added to band $10 \mathrm{C}$ of the cytogenetic map. Note that the cytogenetic positions of $M d m-I$ and $S l$ are inconsistent with their genetic positions relative to one another.

al. 1992). The membrane glycoprotein, alkaline phosphodiester I gene (official name: lymphocyte antigen41, Ly-41; Morse 1992), which has been known for many years as plasma cell antigen-1 (Pca-I), was mapped near the $M y b$ gene (Buckley and Goding 1992). Finally, the transformed mouse 3T3 cell double minute-3 gene $(M d m-3)$, which is amplified and overexpressed in a spontaneously transformed 3T3 cell line, was found to be physically linked to $M d m-2$ (Fakharzadeh et al. 1991).

\section{DNA variants}

Nine DNA sequence variants have been mapped to Chr 10. The xenotropic murine leukemia virus genome, $X m v-39$, shows linkage to $L y-41$ in RI strains (Buckley and Goding 1992; Frankel et al. 1989). Like- wise, a previously described phosphoglycerate kinaserelated sequence (proposed designation, Pgk-1rs6; Adra et al. 1988) shows an SDP identical to $L y-4 l$ in 12 BXH RI strains, suggesting that this sequence is also on Chr 10. Six arbitrary oligonucleotide-primed PCR variants (D10Mc2, D10Byu1, D10Bir1, D10Bir2, D10Bir3, and DloPas3) were mapped to $\mathrm{Chr} 10$ (Birkenmeier et al. 1992; Serikawa et al. 1992; Welsh et al. 1991; Woodward et al. 1992). Two anonymous genomic clones, D10Ler 1 and D10Ler2, were mapped in an interspecific backcross (Le Roy et al. 1992). A pseudogene, ribonucleotide reductase M2 pseudogene-4 $(R r m 2-p s 4)$, was mapped $23.0 \pm 5.4 \mathrm{cM}$ distal to $M y b$ and $13.1 \pm 4.3 \mathrm{cM}$ proximal to $P a h$ (MacLaren et al. 1992). An intra-cisternal A particle long terminal repeat sequence RFLV (Iapls3-21) was detected with an oligonucleotide probe and mapped near D10Byul in the BXD RI strains (Lueders et al. 1993).

\section{Visible mutants and other variants}

A mutation conferring rapid postweaning growth and large mature body size [designated high growth $(h g)$ ] has been mapped in the vicinity of the insulin-like growth factor I gene (Igf-1). Igf-1 is considered a candidate gene for the site of the $h g$ mutation (Medrano et al. 1992). No other visible mutations or other loci defined by functional variants were mapped to Chr 10 .

\section{Human homologies}

Loci that have been added to the map which have also been mapped in human are (with the human localization): Colloa-1 (6q21-q22), Gnaz (22q11), Gnall (19p13), Gna15 (19p13), Lmnb-2 (19p13.3), Ly-41 (6q22-q23), Macs (6q21), Myf5 (12), Myf6 (12) and Pcmt1 (6q22.3-q24). Previously mapped Chr 10 loci whose human homologs have now been mapped are: $P f p$ (10q22) and $M d m-2$ (12q13-q14). The gap junction membrane channel protein-1 (Gja-I), previously assigned to $\mathrm{Chr} 10$, has been placed in the mouse linkage map and further localized in the human map (6q14q24.1). This information is summarized in Table 3. No new regions of homology have been identified. In most cases these assignments do not disrupt previously identified homologous segments. However, the placement of Gnall and Gnal5 $1.7 \mathrm{cM}$ distal to $S 100 \mathrm{~b}$ and Col6a-1/Col6a-2 identifies a region of homology that includes the previously mapped anti-Mullerian hormone $(A m h)$. These loci appear to straddle the $P f p$ locus, which is now assigned to HSA 10q22. However, the placement of $P f p$ is inexact as the nearest anchored markers in the $P f p$-mapping cross are $M y b$ and $I f g$. Rather than postulating that an inversion has intermingled HSA10- and HSA19-homologous regions of $\mathrm{Chr}$ 10, we have somewhat arbitrarily moved Pfp $4 \mathrm{cM}$ toward the centromere until more definitive mapping data are available. This makes $P f p$ contiguous with $H k-1$ and $C d c 2 a$, whose human homologs map to HSA10q. The lamin B2 subunit gene $(L m n b-2)$ was 
Table 3. Newly identified homologies involving mouse $\mathrm{Chr} 10$.

\begin{tabular}{|c|c|c|c|c|c|}
\hline Symbol & Name & Chr position & $\begin{array}{l}\text { Human } \\
\text { position }\end{array}$ & $\begin{array}{l}\text { Human } \\
\text { symbol }\end{array}$ & References \\
\hline Colloa-1 & $\begin{array}{l}\text { procollagen type } X \text {, } \\
\text { alpha } 1\end{array}$ & $\begin{array}{l}\text { close to Macs } \\
\text { and Braf }\end{array}$ & $6 q 21-q 22$ & COL10A1 & 3 \\
\hline$G j a-1$ & $\begin{array}{l}\text { gap junction membrane } \\
\text { channel protein-1 } \\
\text { (connexin-43) }\end{array}$ & $\begin{array}{l}1 \mathrm{cM} \text { distal to } \\
\text { Ros-1 }\end{array}$ & $6 q 14-q 24.1$ & GJA1 & 45 \\
\hline Gnall & $\begin{array}{l}\text { guanine nucleotide binding } \\
\text { protein, alpha subunit-11 }\end{array}$ & $\begin{array}{l}0 \mathrm{cM} \text { from } \\
\text { Gnals }\end{array}$ & $19 \mathrm{p} 13$ & GNA11 & 117 \\
\hline Gnals & $\begin{array}{l}\text { guanine nucleotide binding } \\
\text { protein, alpha subunit-15 }\end{array}$ & $\begin{array}{l}1.7 \mathrm{cM} \text { distal to } \\
\text { S100b }\end{array}$ & $19 p 13$ & GNA15 & 117 \\
\hline Gmaz & $\begin{array}{l}\text { guanine nucleotide binding } \\
\text { protein, alpha } \mathrm{z} \text { subunit }\end{array}$ & $\begin{array}{l}0.5 \pm 0.5 \mathrm{cM} \\
\text { distal to } B C r\end{array}$ & $22 q 11$ & GNAZ & 117 \\
\hline Lmnb-2 & lamin $\mathrm{B} 2$ subunit & $10 \mathrm{C}$ & $19 p 13.3$ & LMNB2 & 8 \\
\hline$L y-41$ & $\begin{array}{l}\text { lymphocyte alloantigen- } \\
41 ; \text { membrane } \\
\text { glycoprotein (alkaline } \\
\text { phosphodiesterase I); } \\
\text { plasma cell antigen-1 }\end{array}$ & near $M y b$ & $6 q 22-23$ & M6S1 & 16 \\
\hline Pcmil & $\begin{array}{l}\text { guanine nucleotide binding } \\
\text { protein, alpha subunit-11 }\end{array}$ & $\begin{array}{l}8.2 \pm 3.5 \mathrm{cM} \\
\text { proximal to } \\
M y b\end{array}$ & $6 q 22.3-24$ & PCMT1 & 67 \\
\hline$P f p$ & perforin & $\begin{array}{l}\text { Myb 23 } \pm 4.5 \\
\text { Pfp } 11.1 \pm 3.3 \\
\text { Tra- } 1\end{array}$ & $10 \mathrm{q} 22$ & PRF1 & 34 \\
\hline Macs & $\begin{array}{l}\text { MARCKs (myristoylated, } \\
\text { alanine-rich C-kinase } \\
\text { substrate) }\end{array}$ & $\begin{array}{l}7 \mathrm{cM} \text { distal to } \\
M y b\end{array}$ & $6 q 21$ & MACS & 10 \\
\hline$M d m-2$ & murine double minutes- 2 & $\begin{array}{l}\text { close to } M d m- \\
1, \text { in situ, co- } \\
\text { amplified }\end{array}$ & $12 q 13-14$ & MDM2 & 83 \\
\hline Myf5 & myogenic factor-5 & $\begin{array}{l}1.5 \pm 1.5 \mathrm{cM} \\
\text { distal to } M d m-1 \\
\end{array}$ & 12 & MYF5 & $\begin{array}{l}60 \text { and J.-L. } \\
\text { Guenet (p.c.) }\end{array}$ \\
\hline Myf6 & myogenic faclor -6 & $\begin{array}{l}\text { physically } \\
\text { linked to } M y f 5\end{array}$ & 12 & MYF6 & 13,72 \\
\hline
\end{tabular}

assigned to band $10 \mathrm{C}$, while its human homolog was placed at HSA 19p13.3, adding a fourth gene to the Chr 10/HSA19p conserved synteny group. The 10C cytogenetic assignment is consistent with a predicted genetic position near the other members of this synteny group. Four additional genes syntenic with HSA6 have been mapped to the proximal end of Chr 10, bringing the total number to ten. The Gnaz gene showed a single recombinant with $\mathrm{BCr}$, indicating the existence of a short region of homology to HSA22q11 located between regions homologous to HSA10q and HSA21q.

\section{Recombinant inbred strains}

Table 4 shows the strain distribution patterns for loci typed in various RI strains.

\section{New chromosomal rearrangements}

Seven deletions encompassing the steel locus have been identified and analyzed by Cattanach and coworkers (1993). All seven $S l$ mutations show the grey coat with white spotting on the head and belly that characterizes the $S l$ mutation, but of the six tested, none produced the anemic black-eyed white homozygotes on intercrossing. Instead, pre- and postnatal homozygous lethalities were observed, indicating that damage at loci other than $S l$ had occurred. All seven mutations carried deletions at the $S l$ locus, ranging in size from $2.5 \%$ to $10 \%$ of the chromosome. A new nomenclature has been adopted to describe these deletions. The mutation previously referred to as
$\operatorname{Df}(S l) 12 \mathrm{H}$ (Cattanach et al. 1988) is now given the complete designation Del $(10) S l^{I 2} 1 \mathrm{H}$, with the abbreviated designation $S l^{12 H}$. Likewise, Df(SD)18H (Cattanach and Rasberry 1988) is now $\operatorname{Del}(10) S l^{18} 2 \mathrm{H}$, with the abbreviated designation $S l^{18 H}$. Five other $S l$ deletions are designated $\operatorname{Del}(10) S l^{20} 8 \mathrm{H}, \operatorname{Del}(10) S l^{22} 12 \mathrm{H}$,

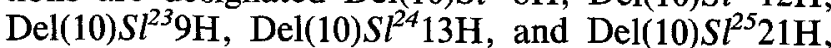
with abbreviated symbols $S l^{20 H}, S l^{22 H}, S l^{23 H}, S l^{24 H}$, and $S l^{25 H}$, respectively. Crosses between $S l^{22 H}$, $S L^{23 H}$, and $S l^{24 H}$ revealed that $S l^{24 H}$, which gives an early post-implantation homozygous lethality, complements $S l^{22 H}$ and $S l^{23 H}$, which give pre-implantation homozygous lethalities, such that anemic black-eyed white compounds are produced and survive to birth. Complementation was not found in $S l^{22 H} / S l^{23 H}$ compounds. $S l^{24 H}$ would therefore appear to represent a deletion in a different region of the chromosome from that of $S l^{22 H}$ and $S l^{23 H}$. All of the new deletions had breakpoints in 10D1. The authors note that the heterozygous viability of large deletions including the $S I$ locus indicates that the genes in this region are either unimportant in development or else their dosage is not critical. The fact that other genes have not been mapped in the vicinity of $S l$ is consistent with this view.

\section{Imprinting}

Experiments have been conducted to test for the effects of imprinting on Chr 10 (Beechey and Cattanach 1992). Mice doubly heterozygous for $\mathrm{Rb}(1.10) 10 \mathrm{Bnr}$ and $\mathrm{Rb}(10.11) 8 \mathrm{Bnr}$ were intercrossed, and downless $(d l)$ was used as a marker for detecting uniparental 
Table 4. RI SDPs.

\begin{tabular}{|c|c|c|c|c|c|c|c|c|c|c|c|c|c|c|c|c|c|c|c|c|c|c|c|c|c|c|c|c|c|}
\hline \multicolumn{30}{|c|}{ BXD (C.57BL/6J $\times$ DBA/2J) } \\
\hline & 0 & & $\begin{array}{l}0 \\
5\end{array}$ & 0 & 0 & $\begin{array}{l}0 \\
9\end{array}$ & & & 1 & & 1 & & & & & 2 & 2 & & & & & & & $\begin{array}{l}2 \\
8\end{array}$ & & $\begin{array}{l}3 \\
0\end{array}$ & 3 & & \\
\hline Mpmv-5 & D & D & $\bar{D}$ & B & $\mathrm{D}$ & H & & 3 & B & B & $\bar{B}$ & $\mathbf{B}$ & $\bar{B}$ & D & $\bar{D}$ & B & $\mathbf{B}$ & E & & & $\bar{B}$ & D & B & $\bar{D}$ & B & $\mathrm{D}$ & $\bar{B}$ & & 40 \\
\hline DIOBуй ${ }^{*}$ & D & D & D & B & D & b & & 3 & D & B & B & B & B & D & D & B & $\mathbf{B}$ & 1 & & & B & D & B & D & B & D & B & & 123 \\
\hline D10Bir2* & D & D & D & B & D & $\mathbf{B}$ & & 3 & D & B & B & B & B & D & D & B & B & $\mathbf{F}$ & 1 & & B & D & B & D & B & D & B & D & 9 \\
\hline Iapls3-21* & D & D & D & B & D & D & & 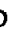 & D & B & B & B & B & D & D & B & B & $\mathbf{E}$ & 1 & & B & D & B & D & B & D & B & & 62 \\
\hline DloMit3 & & D & D & B & B & B & & B & B & B & D & $\mathrm{D}$ & B & B & B & B & D & I & 1 & & D & D & B & D & B & & & & 30 \\
\hline DloMit120 & & D & D & B & D & B & & B & B & & D & B & D & D & B & B & D & F & & & D & B & B & D & B & & & & 30 \\
\hline DloMit10 & & D & D & D & D & F & & 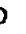 & B & B & D & B & D & D & B & B & D & F & & & $\mathrm{D}$ & D & D & D & B & & & & 30 \\
\hline D10Mitl & & D & D & D & D & F & & 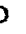 & B & B & D & B & D & D & B & B & D & E & & & D & D & D & D & B & & & & 30 \\
\hline D10Mc2* & B & D & D & D & B & P & & 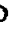 & B & B & D & B & D & D & B & B & D & 1 & & & D & D & D & & & & & & 116 \\
\hline DIOBirl* & B & D & D & D & B & B & & 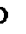 & B & B & B & D & D & D & B & B & D & I & & & D & D & D & D & B & B & B & & 9 \\
\hline$x m v-31$ & B & D & B & D & B & I & & 3 & B & B & B & D & D & D & B & B & 1 & I & & & D & D & D & D & B & B & B & & 38 \\
\hline Ms15-8 & B & D & B & D & B & $\mathbf{H}$ & & 3 & B & B & B & B & D & D & B & B & 1 & I & & & D & D & D & D & B & B & B & & 50 \\
\hline$M d m-1^{*}$ & B & D & B & D & & & & & & & & B & D & D & D & D & 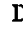 & I & & & D & D & D & D & B & B & D & & 112 \\
\hline DIOMit14 & & D & B & D & B & I & & 3 & B & B & B & B & D & D & D & D & $\mathrm{L}$ & I & & & D & D & D & D & B & & & & 30 \\
\hline$M s 6-3$ & B & D & B & D & B & I & & D & B & B & B & B & D & D & D & $D$ & I & I & & & D & D & B & D & B & B & D & & 50 \\
\hline
\end{tabular}

\section{$\mathrm{AKXD}(\mathrm{AKR} / \mathrm{D} \times \mathrm{DBA} / 2)$}

\begin{tabular}{|c|c|c|c|c|c|c|c|c|c|c|c|c|c|c|c|c|c|c|c|c|c|c|c|c|c|c|}
\hline Locus & $\begin{array}{l}0 \\
1\end{array}$ & $\begin{array}{l}0 \\
2 \\
\end{array}$ & $\begin{array}{l}0 \\
3 \\
\end{array}$ & $\begin{array}{l}0 \\
6 \\
\end{array}$ & $\begin{array}{l}0 \\
7 \\
\end{array}$ & $\begin{array}{l}0 \\
8 \\
\end{array}$ & $\begin{array}{l}0 \\
9 \\
\end{array}$ & $\begin{array}{l}1 \\
0 \\
\end{array}$ & $\begin{array}{l}1 \\
1 \\
\end{array}$ & $\begin{array}{l}1 \\
2 \\
\end{array}$ & $\begin{array}{l}1 \\
3 \\
\end{array}$ & $\begin{array}{l}1 \\
4 \\
\end{array}$ & $\begin{array}{l}1 \\
5\end{array}$ & $\begin{array}{l}1 \\
6 \\
\end{array}$ & $\begin{array}{l}1 \\
7 \\
\end{array}$ & $\begin{array}{l}1 \\
8 \\
\end{array}$ & $\begin{array}{l}2 \\
0 \\
\end{array}$ & $\begin{array}{l}2 \\
1 \\
\end{array}$ & $\begin{array}{l}2 \\
2 \\
\end{array}$ & $\begin{array}{l}2 \\
3 \\
\end{array}$ & $\begin{array}{l}2 \\
4 \\
\end{array}$ & $\begin{array}{l}2 \\
5 \\
\end{array}$ & $\begin{array}{l}2 \\
6 \\
\end{array}$ & $\begin{array}{l}2 \\
7 \\
\end{array}$ & $\begin{array}{l}2 \\
8 \\
\end{array}$ & Refer \\
\hline DIONdsI & D & $\mathbf{A}$ & $\mathbf{A}$ & A & $\mathbf{A}$ & $\mathbf{A}$ & $\mathbf{A}$ & D & D & A & D & $\mathbf{A}$ & $\mathrm{D}$ & D & & D & $\mathbf{A}$ & $\mathbf{A}$ & $\mathbf{A}$ & D & $\mathbf{A}$ & A & D & D & D & 26 \\
\hline DIOBir3* & D & $\mathbf{A}$ & $\mathbf{A}$ & $\mathbf{A}$ & $\mathbf{A}$ & $\mathbf{A}$ & $\mathbf{A}$ & D & D & $\mathbf{A}$ & D & A & $\mathrm{D}$ & $\mathbf{D}$ & $\mathrm{D}$ & $\mathrm{D}$ & $\mathbf{A}$ & $\mathbf{A}$ & A & $\mathrm{D}$ & $\mathbf{A}$ & $\mathbf{A}$ & D & $\mathrm{D}$ & D & 9 \\
\hline Mpmv-12 & $\mathbf{A}$ & $\mathbf{A}$ & $\mathbf{A}$ & $\mathbf{A}$ & $\mathbf{A}$ & $\mathbf{A}$ & $\mathbf{A}$ & D & D & $\mathbf{A}$ & D & A & & D & & D & D & D & $\mathbf{A}$ & $\mathrm{D}$ & D & $\mathbf{A}$ & $\mathbf{A}$ & $\mathrm{D}$ & D & 40 \\
\hline Gad-Ips & $\mathrm{D}$ & D & D & $\mathbf{A}$ & $\mathbf{A}$ & D & D & $\mathbf{A}$ & $\mathrm{D}$ & $\mathbf{A}$ & $\mathrm{D}$ & $A$ & $\mathbf{A}$ & A & A & A & $\mathbf{A}$ & $D$ & $\mathbf{A}$ & $\mathrm{D}$ & $\mathrm{D}$ & $\mathbf{A}$ & A & $\mathbf{A}$ & D & 14 \\
\hline DIONds2 & $\mathbf{A}$ & D & $\mathrm{D}$ & $\mathbf{A}$ & A & D & D & $\mathbf{A}$ & D & $\mathbf{A}$ & $\mathrm{D}$ & $\mathbf{A}$ & $\mathbf{A}$ & $\mathbf{A}$ & & $\mathbf{A}$ & $\mathbf{A}$ & D & $\mathbf{A}$ & D & $\mathrm{D}$ & $\mathbf{A}$ & $\mathbf{A}$ & $\mathbf{A}$ & D & 26 \\
\hline$X m v-31$ & $\mathbf{A}$ & D & $\mathbf{A}$ & $\mathbf{A}$ & $\mathbf{A}$ & D & $\mathbf{D}$ & $\mathbf{A}$ & $\mathbf{A}$ & $\mathbf{A}$ & D & $\mathbf{A}$ & $\mathbf{A}$ & $\boldsymbol{A}$ & $A$ & $\mathbf{A}$ & $\mathbf{A}$ & D & $\mathbf{A}$ & D & $\mathrm{D}$ & $\mathbf{A}$ & $\mathbf{A}$ & D & D & 38 \\
\hline$M d m-I^{*}$ & $\mathbf{A}$ & D & $\mathbf{A}$ & D & $\mathbf{A}$ & $\mathrm{D}$ & D & $\mathbf{A}$ & $\mathbf{A}$ & $\mathbf{A}$ & $\mathbf{A}$ & D & $\mathbf{A}$ & $\mathbf{A}$ & $\mathbf{A}$ & $\mathbf{A}$ & D & D & $\mathbf{A}$ & $\mathbf{A}$ & D & $\mathbf{A}$ & $\mathbf{A}$ & $\mathbf{A}$ & D & 112 \\
\hline
\end{tabular}

\begin{tabular}{|c|c|c|c|c|c|c|c|c|c|c|c|c|c|c|c|c|c|c|c|}
\hline Locus & $\begin{array}{l}0 \\
5\end{array}$ & $\begin{array}{l}0 \\
6\end{array}$ & $\begin{array}{l}0 \\
7\end{array}$ & $\begin{array}{l}0 \\
8\end{array}$ & $\begin{array}{l}0 \\
9\end{array}$ & $\begin{array}{l}1 \\
2\end{array}$ & $\begin{array}{l}1 \\
3\end{array}$ & $\begin{array}{l}1 \\
4\end{array}$ & $\begin{array}{l}1 \\
6\end{array}$ & $\begin{array}{l}1 \\
7\end{array}$ & $\begin{array}{l}1 \\
9\end{array}$ & $\begin{array}{l}2 \\
1\end{array}$ & $\begin{array}{l}2 \\
4\end{array}$ & $\begin{array}{l}2 \\
5\end{array}$ & $\begin{array}{l}2 \\
8\end{array}$ & $\begin{array}{l}2 \\
9\end{array}$ & $\begin{array}{l}3 \\
7\end{array}$ & $\begin{array}{l}3 \\
8\end{array}$ & References \\
\hline$X m v-39 *$ & L & $\mathbf{A}$ & $\mathbf{A}$ & $\mathbf{L}$ & L & L & L & $\mathbf{L}$ & L. & $A$ & $A$ & $\mathbf{A}$ & $\mathbf{L}$ & $\mathbf{A}$ & $\mathbf{A}$ & $\mathbf{A}$ & $\mathbf{A}$ & $\mathbf{A}$ & 38 \\
\hline$M y b^{*}$ & $\mathbf{L}$ & $\mathbf{A}$ & $\mathbf{A}$ & $\mathbf{L}$ & $\mathbf{L}$ & L & $\mathbf{L}$ & L & $\mathbf{L}$ & $\mathbf{A}$ & $\mathbf{A}$ & $\mathbf{A}$ & L & $\mathbf{A}$ & $A$ & A & $\boldsymbol{A}$ & $\mathbf{A}$ & 16 \\
\hline$L y-4 I^{*}$ & $\mathbf{A}$ & $\mathbf{A}$ & $\boldsymbol{A}$ & $\mathbf{A}$ & $\mathbf{L}$ & $\mathrm{L}$ & $\mathbf{L}$ & L & L. & $\boldsymbol{A}$ & $\mathbf{L}$ & $\mathbf{A}$ & $\mathrm{L}$ & $\mathbf{A}$ & $\mathbf{A}$ & $\mathbf{A}$ & $\mathbf{A}$ & $\mathbf{A}$ & 16 \\
\hline Gad-Ips & $\mathbf{L}$ & $\mathbf{A}$ & $\boldsymbol{A}$ & $\mathbf{L}$ & $\mathbf{A}$ & L & $\mathbf{A}$ & $\mathbf{A}$ & $\mathbf{A}$ & $\mathbf{L}$ & $\mathbf{A}$ & $\mathbf{A}$ & L & $\mathbf{L}$ & $\mathbf{L}$ & $\mathbf{L}$ & $\mathbf{A}$ & L & 14 \\
\hline$M d m-l^{*}$ & $\mathbf{A}$ & $\mathbf{A}$ & L & L & $\mathbf{A}$ & L & $\mathbf{A}$ & $\mathbf{L}$ & $\mathbf{A}$ & $\mathbf{L}$ & $\mathbf{A}$ & $\mathrm{L}$ & $\mathbf{L}$ & $\mathrm{L}$ & $\mathbf{A}$ & $\mathbf{L}$ & A & L. & 112 \\
\hline
\end{tabular}

SWXL (SWR/J $\times$ CSTLI)

\begin{tabular}{lcccccccc}
\hline & 0 & 0 & 1 & 1 & 1 & 1 & 1 & \\
Locus & 4 & 7 & 2 & 4 & 5 & 6 & 7 & Reference \\
\hline$H s d$ & S & S & L & S & L & S & S & 4 \\
\hline
\end{tabular}

BXH (C57BL/6J $\times$ C3H/He)

\begin{tabular}{|c|c|c|c|c|c|c|c|c|c|c|c|}
\hline Locks & $\begin{array}{l}0 \\
2\end{array}$ & $\begin{array}{l}0 \\
3\end{array}$ & $\begin{array}{ll}0 & 0 \\
4 & 6\end{array}$ & $\begin{array}{ll}0 & 0 \\
6 & 7 \\
\end{array}$ & $\begin{array}{ll}0 & 0 \\
8 & 9 \\
\end{array}$ & $\begin{array}{l}1 \\
0\end{array}$ & $\begin{array}{l}1 \\
1 \\
\end{array}$ & $\begin{array}{l}1 \\
2 \\
\end{array}$ & $\begin{array}{l}1 \\
4 \\
\end{array}$ & $\begin{array}{l}1 \\
9\end{array}$ & Reference \\
\hline Mpmv-5 & $\mathbf{H}$ & B & H B & 3 & $\mathrm{HH}$ & B & $\mathrm{H}$ & B & $\mathrm{H}$ & $H$ & 40 \\
\hline$P g k-r s \sigma^{*}$ & $\mathbf{H}$ & B & H B & H & H B & $\mathbf{B}$ & B & H & $\mathrm{H}$ & $\mathbf{H}$ & 2 \\
\hline$L y-41^{*}$ & $\mathbf{H}$ & $\mathbf{B}$ & H B & $\mathbf{H}$ & H B & $\mathbf{B}$ & B & $\mathbf{H}$ & H & $\mathbf{H}$ & 16 \\
\hline$H s d$ & $\mathbf{B}$ & H & B $\mathbf{H}$ & I H & B H & $\mathbf{H}$ & B & $\mathbf{H}$ & B & $\mathbf{H}$ & 4 \\
\hline Gad-Ips & B & $\mathbf{H}$ & B $\mathrm{H}$ & H & $\mathbf{H ~ H}$ & $\mathbf{H}$ & $\mathbf{B}$ & H & B & $\mathbf{H}$ & 14,112 \\
\hline$M d m-I^{*}$ & B & $\mathbf{B}$ & $\mathbf{B} \mathbf{B}$ & $\mathrm{H}$ & $\mathrm{H} \mathrm{H}$ & H & B & H & $\mathbf{B}$ & $\mathrm{H}$ & 112 \\
\hline
\end{tabular}

\begin{tabular}{lcccccccc}
\multicolumn{10}{c}{ CXB (BALB/CBy } & C57BL/6By) \\
\hline Locus: & D & E & G & H & I & J & K & Reference \\
\hline$M p m v-5$ & C & B & B & B & B & B & C & 40 \\
$M y b^{*}$ & C & B & B & B & B & B & C & 16 \\
$M p m v-12$ & C & B & B & B & B & B & C & 40 \\
$L y-41^{*}$ & C & B & B & B & B & B & C & 16 \\
$H s d$ & B & C & B & C & B & C & C & 4 \\
Xmv-31 & B & C & B & B & B & C & C & 38 \\
$M d m-1^{*}$ & B & C & B & C & B & B & B & 112 \\
$G l i$ & B & C & B & B & C & B & B & 55
\end{tabular}


Table 4. Continued.

\begin{tabular}{|c|c|c|c|c|c|c|c|c|c|c|c|c|c|c|c|c|c|c|c|c|c|c|c|c|c|}
\hline \multicolumn{26}{|c|}{$\mathrm{AXB}(\mathrm{A} / \mathrm{J} \times \mathrm{C} 57 \mathrm{BL} / 6 \mathrm{~J})$} \\
\hline & 0 & 0 & 0 & 0 & 0 & 0 & 0 & 0 & 0 & 1 & 1 & 1 & 1 & 1 & 1 & 1 & 1 & 1 & 2 & 2 & 2 & 2 & 2 & 2 & \\
\hline Locus & 1 & 2 & 3 & 4 & 5 & 6 & 7 & 8 & 9 & 0 & 1 & 2 & 3 & 4 & 5 & 7 & 8 & 9 & 0 & 1 & 2 & 3 & 4 & 5 & Reference \\
\hline Mpmv-5 & B & A & B & B & $\mathbf{A}$ & B & $\mathbf{B}$ & A & $\mathbf{A}$ & $\mathbf{A}$ & B & A & B & $\mathbf{B}$ & $\mathbf{A}$ & $\mathbf{A}$ & B & $\mathbf{A}$ & B & $\mathbf{A}$ & B & B & B & $\mathbf{A}$ & 40 \\
\hline DIONds $1^{*}$ & $\mathbf{B}$ & $\mathbf{A}$ & $\mathbf{B}$ & B & $\mathbf{A}$ & B & B & A & A & A & B & A & $\mathbf{B}$ & $\mathbf{B}$ & A & $\mathbf{A}$ & B & B & B & $\mathbf{A}$ & & B & $\mathbf{B}$ & & 75 \\
\hline DloMit2* & A & A & $\mathbf{A}$ & B & A & $\mathbf{A}$ & B & $\mathbf{A}$ & $\mathbf{A}$ & A & B & & B & B & A & A & B & B & B & $\mathbf{B}$ & & B & A & & 75 \\
\hline$M y b^{*}$ & A & $\mathbf{A}$ & $\mathbf{A}$ & B & A & A & B & A & A & A & B & $\mathbf{B}$ & B & $\mathbf{B}$ & & & B & & B & $\mathbf{B}$ & $\mathbf{B}$ & B & A & $\mathbf{A}$ & 40 \\
\hline$M p m v-12$ & A & $\mathbf{A}$ & $\mathbf{A}$ & B & A & A & B & A & A & $\mathbf{A}$ & B & B & $\mathbf{B}$ & B & $\mathbf{A}$ & A & B & B & $\mathbf{B}$ & $\mathbf{B}$ & B & B & A & A & 40 \\
\hline DloMitlo* & B & A & B & B & $\mathbf{A}$ & B & A & B & A & A & B & B & H & $\mathbf{B}$ & B & B & B & B & B & $\mathbf{B}$ & & A & B & & 75 \\
\hline DloMit14* & B & $\mathbf{B}$ & $\mathbf{A}$ & B & $\mathbf{A}$ & B & A & A & A & A & A & B & B & B & A & B & A & B & B & B & & B & $\mathbf{B}$ & & 75 \\
\hline
\end{tabular}

BXA (C57BL/6J X A/J)

\begin{tabular}{|c|c|c|c|c|c|c|c|c|c|c|c|c|c|c|c|c|c|c|c|c|c|c|c|}
\hline & 0 & 0 & 0 & 0 & 0 & 0 & 0 & 1 & 1 & 1 & 1 & 1 & 1 & 1 & 1 & 1 & 2 & 2 & 2 & 2 & 2 & & \\
\hline Locus & 1 & 2 & 4 & 6 & 7 & 8 & 9 & 0 & 1 & 2 & 3 & 4 & 6 & 7 & 8 & 9 & 0 & 2 & 3 & 4 & 5 & 6 & Reference \\
\hline Mpmv-S & A & A & A & B & $\mathbf{B}$ & $\mathbf{B}$ & B & A & B & B & A & $\mathbf{B}$ & $A$ & $\mathbf{B}$ & A & B & $\mathbf{A}$ & A & B & $\mathbf{B}$ & B & A & 40 \\
\hline DIONdsI* & A & $\mathbf{A}$ & $\mathbf{A}$ & & B & B & $\mathbf{B}$ & & B & $\mathbf{B}$ & $\mathbf{A}$ & $\mathbf{B}$ & $\mathbf{A}$ & B & A & & A & A & $\mathbf{B}$ & A & $\mathbf{B}$ & A & 75 \\
\hline DIOMit2* & B & A & $\mathbf{A}$ & & B & B & B & & B & B & A & B & A & $\mathbf{B}$ & A & & B & A & B & A & B & $\mathbf{B}$ & 75 \\
\hline$M y b$ & B & $\mathbf{A}$ & $\mathbf{A}$ & $\mathbf{B}$ & $\mathbf{B}$ & B & B & A & B & B & $\mathbf{A}$ & B & & B & A & $\mathbf{A}$ & $\mathbf{B}$ & $\mathbf{A}$ & B & $\mathbf{A}$ & $\mathbf{B}$ & & 40 \\
\hline Mpmv-12 & $\mathbf{B}$ & A & A & B & $\mathbf{B}$ & $\mathbf{B}$ & B & A & B & B & A & B & $A$ & B & A & A & B & A & $\mathbf{B}$ & A & B & $\mathbf{B}$ & 40 \\
\hline DIOMit10* & B & $\mathbf{A}$ & $\mathbf{B}$ & & $\mathbf{B}$ & B & B & & B & B & A & $\mathbf{B}$ & B & $\mathbf{B}$ & A & & $\mathbf{A}$ & A & A & $\mathbf{B}$ & B & A & 75 \\
\hline D10Mit14* & B & $\mathbf{B}$ & $\mathbf{B}$ & & B & A & B & & B & B & A & B & $\mathbf{B}$ & A & B & & B & B & A & B & A & A & 75 \\
\hline
\end{tabular}

\section{NXSM (NZB/BLNJ x SM/J)}

\begin{tabular}{llllllllllllllllllllll}
\hline Locus & A & C & D & E & F & I & L & N & P & Q & T1 & T2 & U & V & W & X & Z & Locus \\
\hline Mpmv-12 & S & S & S & N & N & S & S & N & N & S & N & N & N & N & S & S & N & 37 \\
Xmv-54 & S & S & S & N & N & S & S & N & N & N & N & N & N & N & S & N & N & 37 \\
$X m v-31$ & S & N & S & N & N & N & N & N & S & S & N & N & S & N & S & S & S & 37 \\
$X m v-51$ & S & N & S & N & N & N & N & N & S & S & N & N & S & N & S & S & S & 37 \\
$p g$ & N & S & S & N & N & N & N & N & S & S & N & N & S & N & S & S & S & 37 \\
\hline
\end{tabular}

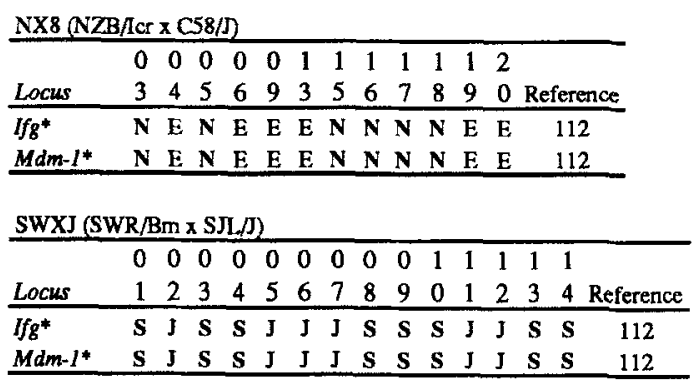

\begin{tabular}{|c|c|c|c|c|c|c|c|c|c|}
\hline $\mathrm{OCL}$ & $\begin{array}{ll}0 & 0 \\
1 & 3\end{array}$ & $\begin{array}{l}0 \\
4\end{array}$ & $\begin{array}{l}0 \\
6\end{array}$ & $\begin{array}{l}0 \\
8\end{array}$ & $\begin{array}{l}0 \\
9\end{array}$ & $\begin{array}{l}1 \\
0\end{array}$ & $\begin{array}{ll}1 & 1\end{array}$ & 1 & \\
\hline Ifg* & C J & $\mathbf{J}$ & $J$ & $\mathrm{C}$ & C & J & C C & C & 112 \\
\hline$M d m-I^{*}$ & C J & $\mathbf{J}$ & $\mathbf{J}$ & C & C & $\mathbf{J}$ & C $\mathrm{C}$ & C & 112 \\
\hline
\end{tabular}

\begin{tabular}{|c|c|c|c|c|c|c|c|c|c|}
\hline Locus & $\begin{array}{l}0 \\
1\end{array}$ & $\begin{array}{l}0 \\
2\end{array}$ & $\begin{array}{l}0 \\
5\end{array}$ & 7 & $\begin{array}{l}1 \\
0\end{array}$ & $\begin{array}{l}1 \\
2\end{array}$ & 7 & 9 & leference \\
\hline If $g^{*}$ & 9 & 9 & $\mathbf{N}$ & 9 & 9 & 9 & 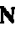 & $\mathbf{N}$ & 112 \\
\hline$M d m-1^{*}$ & 9 & 9 & $\mathbf{N}$ & 9 & 9 & 9 & $\mathbf{N}$ & $\mathbf{N}$ & 112 \\
\hline
\end{tabular}

SDPs of Chr 10 loci in RI strains of mice. The RI strain sets, (e.g., BXD), were derived from crosses between the two progenitor inbred strains (e.g., C57BL/6J $\times \mathrm{DBA} / 2 \mathrm{~J})$ shown at the top of each table. Numbers or letters in the second row of each table identify individual RI strains, and letters in the body of each table denote the inheritance of marker alleles from the respective parents. Newly defined SDPs are denoted by asterisks. Letters in bold are used to highlight alleles
inherited from one of the two progenitor strains of each RI set.

disomy. Both paternal and maternal disomic mice were recovered and were phenotypically normal although they were substantially smaller than their littermates. The authors conclude that the difference in body weight might be explained by homozygosity for $d l$. Thus, there are evidently no genes on Chr 10 for which uniparental inheritance is incompatible with survival. Previous analysis of the $\mathrm{D}(10.18) 18 \mathrm{H}$ translocation had shown that there were no vital genes distal to the Chr 10 breakpoint (band B4).

\section{Reference loci}

Although the six reference loci $(M y b, R o s-1, S 100 b$, $P a h, S l$, and Gli) recommended last year by the com- mittee have the shortcoming that their polymorphism among common inbred strains is largely unknown, we do not feel that there is sufficient grounds for adopting a new set of reference loci at this time.

Acknowledgments. We thank Dr. Eric Lander for providing data prior to publication and Drs. Larry Mobraaten and Joseph Nadeau for their comments on the manuscript. The writing of this report was facilitated by access to GBASE, a mouse genetic database maintained at The Jackson Laboratory by L.J. Maltais, A.L. Hillyard, D.P. Doolittle, M.T. Davisson, J.N. Guidi, and T.H. Roderick. B.A. Taylor received support from National Institutes of Health research grant CA33093. W.N. Frankel is a Special Fellow of The Leukemia Society of America, Inc. 